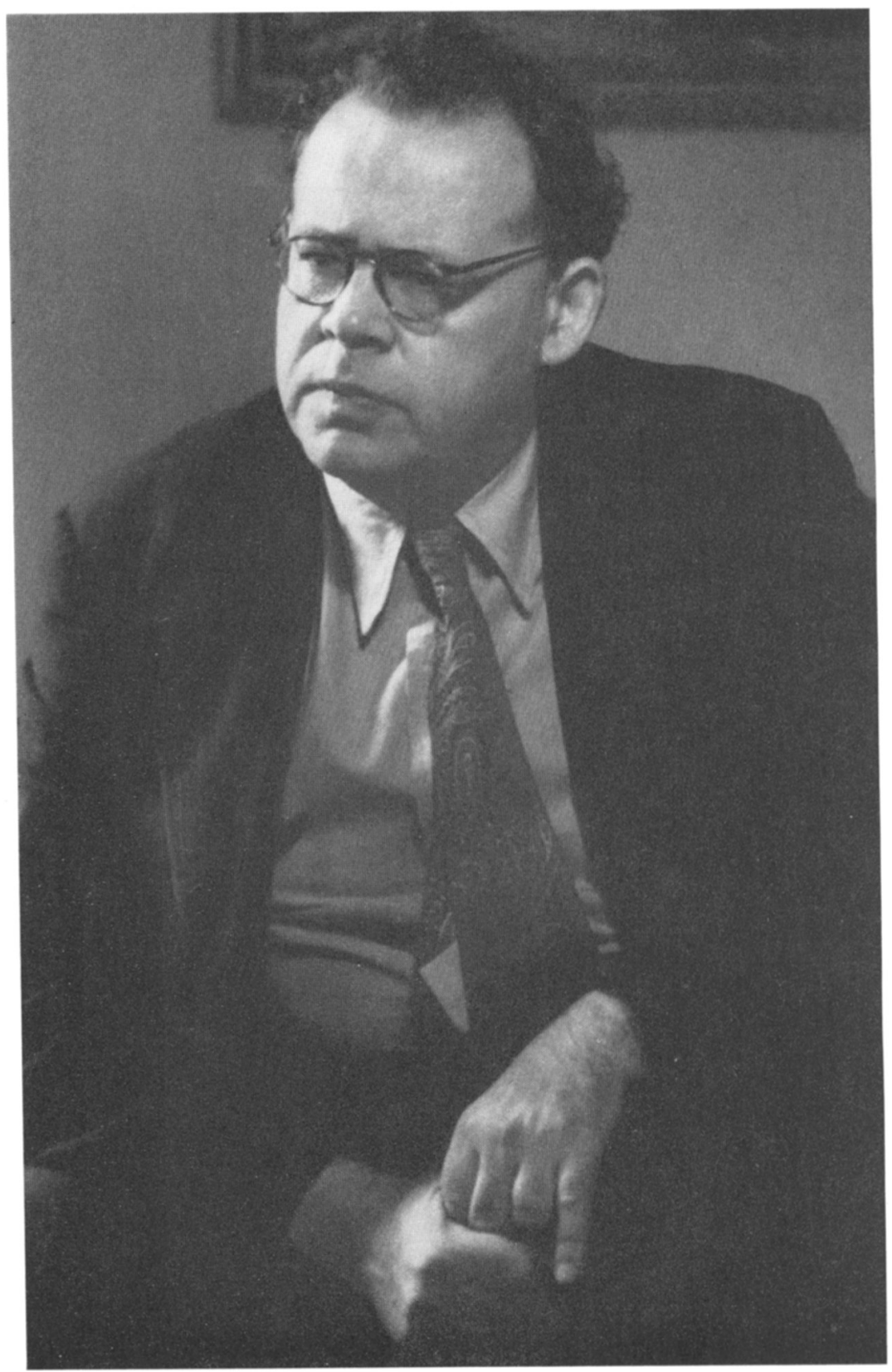

Waldemar Gurian 1902-1954 


\section{Waldemar Gurian}

TO SIT, even temporarily, at the editorial desk of the late 1 Waldemar Gurian and to recall the great erudition, the wide acquaintanceship, and the keen penetration of mind that he brought to his work induces both sorrow at his loss and dismay at the task of replacing him. Even though we had known for months that the end was not far away, there remained the hope that his many plans yet unfulfilled could in some way reach fruition. To each man are given special talents and personal opportunities for preparation and for action, and only that man can use them. Dr. Gurian had grasped in his great mind the fundamental problem of the Western world in the twentieth century: the preservation of the spiritual dignity of man in a civilization where old hatreds and lusts have mounted machines and intensified violence to attain their inhuman purposes; and he consecrated his special gifts to a Christian solution of that problem.

Dr. Gurian had a deep understanding of Western man, partly because of the varied experiences of his youth and his wide associations with persons of many nations, but mostly because he had learned to value the spiritual quality which makes men superior to national and racial barriers. His predominant interest in the political came from his realization that from ancient civilizations to modern mechanical "leviathans" the guardianship of human greatness and the rights to growth of the young and the old in civil life depend upon the concept and the practice of government among men. His devotion to higher journalism came partly from his special talents in that field and partly because he realized the immediacy of the journalist's power over the critical decisions of the day and over the reading public.

Dr. Gurian, in quality a thinker and a scholar, united in his activities the two roles which are most important in the civil community of the twentieth century, that of the politician and that of the journalist. These roles have lost caste in this modern world because both the politician and the journalist have tended to turn from truth and justice and to become the craven servants of propaganda and of vice. The second-rate politician and the 
second-rate journalist alike have been deceived by the shallow reasoning of the agnostic pragmatist or have been trapped by the unnerving luxury of modern comforts, so that they have turned away from the eternal and spiritual character of Christian man. Dr. Gurian spurned the craven politician and the corrupt journalist and devoted his talents to the correct solution of the modern political crisis and to the propagation of this solution to the intellectual leaders of the world. Unfortunately, we in America have not yet created the words for describing the good politician and the superior journalist-such words as would best describe Dr. Gurian-the man who writes for those who are aware, intellectually and spiritually, of the deepest conflict of the present age.

To those who are members of active minorities, there come rew tributes in the popular press, fewer decorative medals and citations; there is usually only the satisfaction of tyrants being checked, of minorities being defended, of forgotten truths raised on high. But there is the hope that the now unrecognized work will some day receive its due honor. To all this, Dr. Gurian has added suffering for truth and justice, exile, and persecution and a body all too soon consumed by the zeal that felt time was running out. We cannot here record all that he accomplished; we can merely mention some of his aims and efforts; and we can hope that his zeal for truth and justice will be carried on by intellectual and stouthearted men.- Thomas T. McAvoy, c.s.c. 